\title{
The Access of the Young Graduates in Sciences into R\&D Profession: A Switching Model Treatment for the French Case
}

\author{
Claire Bonnard
}

\author{
Published in Labour, Volume 26, Issue 1, 2012, p. 23-38 \\ DOI: $10.1111 / \mathrm{j} .1467-9914.2011 .00535 . \mathrm{x}$
}

\begin{abstract}
We address the question concerning the choice of graduates in sciences and engineering to look for employment in research and development. We use an endogenous switching regression to avoid the existence of self-selection biases. The study shows that human capital is decisive where both employment opportunities and remuneration are concerned within, but not without, this sector. The results also suggest that in the early stages of a career, the R\&D sector is less rewarding than other types of employment only for doctors and not for graduates from engineering schools.
\end{abstract}

\section{Introduction}

Because of the current policy as regards the development of innovation, scientific employment in the private sector is now considered a major issue. Indeed, Redor (2004) showed that 'the number and qualifications of researchers, but also their internal mobility, are factors underlying the innovation capacity of firms'. The fear of a shortage of young researchers and engineers, in particular the declining number of graduates getting involved in scientific professions, is the subject of much debate both in the USA (Brown and Linden, 2008; Butz et al., 2003) and in the European Union (Becker, 2010; Gago, 2004). However few studies have focused on the opportunities of young graduates to get involved in R\&D or the potential wage returns for choosing such a career.

In France, the number of publications does not seem to be a criterion for recruitment in the private sector (Giret et al., 2007; Mangematin, 2000), unlike what happens in the academic sector. Moreover, the productivity of researchers in the private sector has not been deeply studied. In this paper, we inquire into the decisive factors making it possible to secure a position in $R \& D$. In the course of the hiring process, do employers assess only the human capital of young graduates or do they use other sources of information, like signals such as the networks in which graduates participate or the companies in which they were trainees?

The data are taken from the survey 'Generation 2004' conducted by the CEREQ. ${ }^{1}$ This survey involved about 33,000 people interviewed in 2007 about the context of the degree of their involvement in the labour force, 3 years after they had left school. This study only focuses on graduates having had at least 5 years of higher education, attended scientific curricula and

\footnotetext{
${ }^{1}$ Centre d'Etudes et de Recherches sur les Qualifications
} 
who are working in the private sector, the subsample after this selection representing about 1,100 people. We choose an endogenous regression model ('endogenous switching regression'), also called the 'Mover/Stayer' model, to address the existence of self-selection biases. We can indeed assume that unobservable characteristics affecting both the fact of working in R\&D and wages determination may lead to selection biases. This method makes it possible to put into place both an estimate of earnings functions and a selection equation based on the full information maximum-likelihood (FIML) method.

First, the determinants that allow graduates to get employment in private-sector R\&D were analysed for graduates in sciences. The models were estimated separately for doctors and graduates from engineering schools, in order to determine whether there is a 'differentiation' in selection for R\&D employment between these two degrees. The remuneration of graduates was then analysed in both research and non-research sectors. This analysis will in particular enable us to compare the return on investment based on wages, for the various degrees and for both types of employment. Finally, conditional and unconditional wages were predicted, based on the estimated parameters in order to measure the significance in wage gap between $\mathrm{R} \& \mathrm{D}$ and other types of employment for each type of degree awarded.

2. Review of literature on the determinants of the access to R\&D

\subsection{Access to R\&D}

In the private sector, it is difficult for employers to determine the productivity of a young researcher during the recruitment process. Indeed, $R \& D$ workers are engaged in tasks that are primarily cognitive and before hiring a scientist, the employer cannot easily determine the abilities of the scientist to solve problems, to innovate and performs tasks (Zenger and Lazzarini, 2004). In the academic sector, the productivity of a young researcher can indeed be estimated, by considering, for instance, the number of publications he/she has made (Levin and Stephan, 1991). But some studies dealing with the French case (Giret et al., 2007; Mangematin, 2000) showed that the number of publications did not appear to be a criterion for recruitment in the private sector. Moreover, we can note that the productivity of researchers in the private sector has not been studied much in terms of pure economic efficiency. What are the determinants making it possible to secure an R\&D position? When hiring, do employers take into account only the human capital of graduates (degree, professional experience) or also other signals such as networks graduates are part of or the colleges that they graduated from?

\subsubsection{The role of the degree.}

According to Stephan (quoted by Graham and Smith, 2005), the Science and Engineering (S\&E) profession gives more significance to measurable skills and knowledge than to less tangible traits such as personality or appearance (which may carry greater weight in some non-S\&E jobs such as management, sales and services). In this perspective, a doctor's degree 
should be given priority by companies over other types of degrees where R\&D positions are concerned, especially as the current policy aims to bring together academia and private R\&D laboratories. However, companies still have a marked preference for graduates from engineering schools at the expense of doctors (Observatoire de l'emploi scientifique, 2007). In literature, this phenomenon is primarily explained by the fact that companies blame doctors for not knowing the business world well enough as graduates from engineering schools generally train for long periods of time in companies (Duhautois and Maublanc, 2005, 2006). On the other hand, during their careers, researchers in the private sector will often choose to work in other sectors such as managerial positions (Biddle and Roberts, 1994), production and marketing (Beltramo et al., 2000 ; Duhautois and Maublanc, 2005). Companies, therefore, prefer hiring graduates from engineering schools because they believe that these graduates gained broader knowledge and acquired the management skills needed to move to other types of positions, unlike doctors.

We can assume that the professional experience of a graduate, associated with his/her human capital, is also crucial to a position in R\&D. Indeed, as we have seen, it appears that the preference for engineering schools is mainly due to the experience engineering graduates acquired during their studies. Some studies also showed that doctors who work in the private sector are those who were corporate trainees during their $\mathrm{PhD}$ degree. This professional experience was acquired through the funding they received during their doctorate (fellowship $\mathrm{CIFRE}^{2}$ ) or because they signed research contracts with the private sector (Giret et al., 2007; Mangematin, 2000).

\subsubsection{Colleges and universities.}

The colleges in which graduates studied may also be used as a criterion during the recruitment process. For example, Rebick (2000) showed that, in Japan, the ties between universities and companies allow employers to reduce research costs and minimize mismatch in the course of employee selection. He underlined the fact that science teachers can, in some cases, be used as references by placing their best students in companies in which they themselves have connections. These connections also enable graduates to know of the job opportunities in these companies. Lam (2001) also showed that companies tend to maintain close links with universities to target the best students and have influence on their training, a fact the author calls 'extended internal market'. She stressed that these networks offer the recruiter more information on the quality of skills of the applicant than his/her degree does. Finally, companies can also rely on the prestige of the universities (especially engineering schools) applicants graduated from. Indeed, in France, the prestige of the various engineering schools is well known by companies, in particular by the annual rankings published in various magazines and newspapers.

2.1.3. Acquaintances and graduates’ networks.

\footnotetext{
${ }^{2}$ CIFRE (Industrial Convention of Training through Research) is an industrial fellowship
} 
On the other hand, employers may use a spe- cific factor, an 'informal' signal (Saloner, 1985), during the recruitment process of young researchers. A great number of studies analysed the role of social networks in recruitment. Granovetter (1995) showed the informational role of social networks on the labour market. According to this author, networks enable employers and employees alike to obtain better and more reliable information during the recruitment process. In the case of R\&D positions, Simon and Warner (1992) showed, for example, that employers use former graduates' networks during the hiring process of young researchers in order to reduce uncertainty about the productivity of future employees. In a more recent study, Mangematin (2000) also pointed out that doctors often use social networks in order to find employment in the private sector.

\section{$2.2 \quad$ Starting wages}

According to Weiss (1980), when uncertainty about the capabilities of individuals is important, the employer may decide to offer higher starting wages to attract the most talented individuals. At the same time, uncertainty about the productivity of the young researcher may have the opposite effect on starting wages. Mishagina (2008) shows that as at the beginning of their careers, information on the productivity of young researchers is not available, the employer may decide to offer lower wages to individuals working in research compared with those working in other sectors. When information on the capabilities of the individual to do research is revealed, the less productive researchers move on to different positions, whereas the most productive stay in research and will have a higher wage growth. Moen (2005) finds a similar wage profile. Conversely, according to the author, $R \& D$ can be seen as an investment in human capital by the young graduate that can then be exploited in another company or in a different position. Nevertheless, some empirical studies do not seem to confirm this analysis. In France, Beltramo and Paul (1994) and Bourdon and Paul (1992) show that early career earnings in $R \& D$ are significantly lower than in non-research sectors for graduates of engineering schools. They also stress that this wage gap grows throughout the careers of engineers. The same result is found in England by Roberts (2002) and Holland (Dupuy and Smits, 2009). The hypothesis put forward to explain this result is the existence of a 'taste for research' on the part of researchers. According to this hypothesis, researchers are willing to 'pay' for doing research. The study of Stern (2004) seems to confirm this hypothesis. Indeed, as is shown in the USA, doctors of biology are willing to accept lower wages if their job allows them to do their research and publish it.

\section{Methodology}

\subsection{Oaxaca-Blinder decomposition}

The simplest method in order to estimate the profitability of R\&D work is to build a 'single equation’ by ordinary least squares (OLS) as follows: 
In this model, wi represents the annual wages, xi represents several independent variables standing for individual characteristics, and $R \& D$ is a dummy variable corresponding to either a 'research' or a 'non-research' position. The value and significance of the coefficient bR\&D determines the wage gap between the two types of activities. A disadvantage of this approach is that the returns to individual characteristics have to be equal for all positions. An alternative approach is the Oaxaca-Blinder decomposition. This method developed by Blinder (1973) and Oaxaca (1973) makes it possible to divide the wage gap into two components: an 'endowments effect' and a 'coefficient effect'. The 'endowments effect' is the element explained by differences between individual characteristics. The second component corresponds to the 'unexplained' part and is interpreted as providing a measure of whether an identical graduate holding the same position in $R \& D$ or other sectors would receive the same wages (Melly, 2005).

First, this method involves estimating a wage equation separately for graduates working in $\mathrm{R} \& \mathrm{D}$ and those working in other sectors:

$\log \left(\mathrm{w}_{i}\right)^{j}=\beta_{i}^{j} x_{i}+\varepsilon_{i}, j=\mathrm{R} \& \mathrm{D}, \mathrm{OR} \& \mathrm{D}$

Then, we calculate:

$\overline{\log \left(w_{t}\right)^{R \& D}}-\log \left(w_{t}\right)^{H R \& D}=\left(\bar{X}^{R \& D}-\bar{X}^{H R \& D}\right) \hat{\beta}^{H R \& D}+\bar{X}^{R \& D}\left(\hat{\beta}^{R \& D}-\hat{\beta}^{H R \& D}\right)$.

In this equation $\log \left(\mathrm{w}_{t}\right)^{j}$ and $\bar{X}^{j}$ are the average wage log and the average characteristics of graduates in each activity $j$. The first part of the decomposition represents the proportion accounted for by differences between average characteristics ('endowment effect') and the second part represents the proportion accounted for by differences between the profitability levels indicated by these characteristics ('coefficient effect'). ${ }^{3}$

\subsection{Switching regression: Mover/Stayer model}

The Oaxaca-Blinder method may seem unsatisfactory because it does not take into account the unobserved heterogeneity. Indeed, the 'unexplained part' may reflect only differences between unobservable characteristics among the two types of graduates. Some studies (Giret et al., 2003; Lassibille, 2001) suggest that unobservable characteristics affecting both research work and wages exist and may lead to selection biases. Indeed, it seems that R\&D employees tend to have a particular motivation, 'a taste for research'. This motivation cannot be observed by the economist and may bias the estimation results. Several methods can be used to take into account the existence of such biases. The model usually used is the two-step method by

\footnotetext{
${ }^{3}$ The difficulty in the decomposition is the choice of weights. To test the robustness of the results, we also perform the decomposition where we weight the difference in average characteristics by $\hat{\beta}^{R \& D}$. Results do not change significantly.
} 
Heckman (1979). For this paper, we used the Mover/Stayer model, also called 'endogenous switching regression'. Unlike the Heckman procedure, this method allows us to estimate simultaneously earnings functions and a selection equation based on the FIML method, allowing us to obtain more reliable standard errors (Lokshin and Zurab, 2004).

The model takes the following form:

$\ln w_{1 i}=\beta_{1} X_{1 i}+\varepsilon_{1 i}$

$\ln w_{0 \mathrm{i}}=\beta_{0} \mathrm{X}_{0 \mathrm{i}}+\varepsilon_{0 \mathrm{i}}$

$I_{i}^{*}=\delta\left(\ln _{\mathrm{w} 1 \mathrm{i}}-\ln _{\mathrm{w} 0 \mathrm{i}}\right)+\mathrm{Z}_{\mathrm{i}} \gamma+\mathrm{u}_{\mathrm{i}}$

Equations [3] and [4] are earnings functions respectively for the research and non-research sectors. $\mathrm{w}_{1 i}$ and $\mathrm{w}_{0 i}$ are respectively the wages in research and non-research positions. $\mathrm{X}_{1 i}$ and $\mathrm{X}_{0 i}$ are human and social capital variables that allow us to explain wages. Equation 5 is the selection equation, where $I_{i}^{*}$ is a latent variable determining the choice that a graduate has to make between working in the research sector or elsewhere. As $I_{i}^{*}$ cannot be observed by the researcher, it is a dichotomous variable where $\mathrm{I}=1$ if graduates choose to work in research and 0 if they choose to work in other sectors; the result is:

$\mathrm{I}_{\mathrm{i}}=1$ if $I_{i}^{*}>0$

$\mathrm{I}_{i}=0$ otherwise.

$\mathrm{Z}_{i}$ is a set of variables affecting the choice of working in one of the two defined sectors plus instrumental variables. Instrumental variables must not have direct impact on wages. $U_{i}$, $\varepsilon_{1 \text { i, }}$, and $\varepsilon_{2 i}$ are error terms respectively of the selection equation and the earnings function. The model also estimates the correlation coefficients between $\varepsilon_{1 i}$ and $u_{i}$ and $\varepsilon_{0 i}$ and $u_{\mathrm{i}}$, called $p_{1}$ and $p_{0}$. Particular attention should be paid to these coefficients. Indeed, if $p_{0}$ or $p_{1}$ is statistically different from zero, the error term of the selection equation is correlated with error terms of wage equations. In other words, the selection within a particular sector is endogenous to wages. Unobserved characteristics or preferences influencing the fact of working in research or in a different sector probably affect graduates' wages once they are employed (Lokshin and Zurab, 2004).

Table 1. Correlation coefficients

\begin{tabular}{|c|c|c|c|}
\hline$p_{1}$ & $p_{0}$ & Selection in R\&D & $\begin{array}{c}\text { Selection in non- } \\
\text { R\&D }\end{array}$ \\
\hline+ & + & + & - \\
\hline+ & - & + & + \\
\hline- & + & - & - \\
\hline
\end{tabular}




\begin{tabular}{|c|c|c|c|}
\hline- & + & - & - \\
\hline
\end{tabular}

\subsection{Study of correlation coefficients}

The study of correlation coefficients is interesting because it determines whether there is a 'positive' or 'negative' selection in research and non-research sectors. For the analysis of coefficients, we made use of the methodology of Maddala (1983) and Hamilton and Nickerson (2003). After estimating the models, four situations may arise that are presented in Table 1.

3.4 Analysis of the wage gap between the $\mathrm{R} \& \mathrm{D}$ sector and non-research sectors

The Mover/Stayer model enables us to calculate the wage gap by taking into account selection biases. Indeed, after estimating the models, it is possible to calculate the following:

$$
\begin{aligned}
& \mathrm{yc}_{1 \_1 i}=\mathrm{E}\left(\mathrm{y}_{1 i} \mid \mathrm{I}_{i}=1, \mathrm{x}_{1 i}\right)=\mathrm{x}_{1 i} \beta_{1}+\sigma_{1} \rho_{1} f\left(\gamma \mathrm{Z}_{i}\right) / \mathrm{F}\left(\gamma \mathrm{Z}_{i}\right) \\
& \mathrm{yc}_{0 \_0 i}=\mathrm{E}\left(\mathrm{y}_{0 i} \mid \mathrm{I}_{i}=0, \mathrm{x}_{0 i}\right)=\mathrm{x}_{0 i} \beta_{0}+\sigma_{0} \rho_{0} f\left(\gamma \mathrm{Z}_{i}\right) /\left(1-\mathrm{F}\left(\gamma \mathrm{Z}_{i}\right)\right) \\
& \mathrm{yc}_{\mathrm{C}_{\_} 1 i}=\mathrm{E}\left(\mathrm{y}_{0 i} \mid \mathrm{I}_{i}=1, \mathrm{x}_{1 i}\right)=\mathrm{x}_{1 i} \beta_{0}+\sigma_{0} \rho_{0} f\left(\gamma \mathrm{Z}_{i}\right) / \mathrm{F}\left(\gamma \mathrm{Z}_{i}\right) \\
& \mathrm{yc}_{1 \_0 i}=\mathrm{E}\left(\mathrm{y}_{1 i} \mid \mathrm{I}_{i}=1, \mathrm{x}_{0 i}\right)=\mathrm{x}_{0 i} \beta_{1}+\sigma_{1} \rho_{1} f\left(\gamma \mathrm{Z}_{i}\right) /\left(1-\mathrm{F}\left(\gamma \mathrm{Z}_{i}\right)\right) .
\end{aligned}
$$

$\mathrm{yc}_{1 \_1 i}\left(y c_{0_{0 i}}\right)$ are predicted wages of graduates currently working in $\mathrm{R} \& \mathrm{D}$ (in non-research positions) conditionally to the fact that they are working in R\&D (in non-research positions). $\mathrm{yc}_{0_{-} 1 i}$ and $\mathrm{yc}_{1 \_} 0 i$ are counterfactual wages. They actually correspond to the wages of graduates currently working in $R \& D$ (non-research positions) if they were working in non-research positions (R\&D).

From these predicted wages, two indicators can be constructed:

(1) $\prod_{1}=y c_{1 \_1 i}-y c_{0 \_} 1 i$

(2) $\prod_{0}=y c_{1 \_} 0 i-y c_{0 \_} 0 i$

P1 measures the wage difference between the wages earned in R\&D and the wages earned in a different sector for graduates who are currently working in research. If P1 is positive (negative), the R\&D sector is more (less) lucrative than non-research sectors for graduates currently employed in R\&D.

P0 measures the wage difference between the wages earned in R\&D and the wages earned in non-research sectors for graduates who are currently working in non-research sectors. In this case, if P0 is positive (negative), the R\&D sector is more (less) lucrative than non-research sectors for graduates currently employed in non-research sectors. The models are estimated in 
4. Data presentation

The data are taken from the survey 'Generation 2004' conducted by the CEREQ. This study involved about 33,000 people interviewed in 2007 on vocational integration, 3 years after they left the educational system. The survey data give further information about the person and the position he holds 3 years after graduation. In the sample, 1,059 graduates have studied at least 5 years in a scientific field and are employed in the private sector.

31.5 per cent of these graduates are working in $\mathrm{R} \& \mathrm{D}^{5}$ and 68.5 per cent are employed in nonresearch sectors.

\subsection{Individual variables}

Individual variables are the gender and the qualifications of the subject, the subject of the degree he has and the number of months he has been working. In the model including engineers, we also took into account the fact that an engineer may have obtained a different degree from his engineer's degree. In the model including doctors, we also took into consideration the facts that a doctor completed a work placement ${ }^{6}$ during his/her studies, the type of financing (CIFRE) he or she received and his/her career plans throughout the doctorate (academic research/other plans). Descriptive statistics are presented in Appendix B: Table B1 for doctors and B2 for engineers.

\subsection{Social capital variables}

The 'social capital' variable is taken from the following question of the survey: How did you know there was a job opportunity in this company? Possible answers are: through an agency (ANPE, Mission locale, PAIO or APEC ${ }^{7}$ ), your former school, one of your acquaintances, an advertisement (newspapers, the Internet), through a spontaneous application and finally, other people.

Acquaintances and classified ads represent the most important recruitment methods for graduates. Indeed, 50 per cent of graduates on average knew of the existence of a job opportunity leading to a hiring process in one of these two ways. Doctors seem to rely more on their acquaintances than other graduates (35 per cent against 22 per cent). Mangematin (2000) pointed out that doctors often use their contacts to find jobs in the private sector. Table

\footnotetext{
4 The movestay command is used to estimate models.

${ }^{5}$ To define the R\&D activities, we use the nomenclature developed by Audric-Lerenard and Topol (1999) (see Appendix A).

${ }^{6}$ For the work placement, the doctors who received a CIFRE funding are not taken into account.

${ }^{7}$ ANPE: French national employment agency; APEC: employment agency for professionals and managers; PAIO: career information centers.
} 
2 shows a differentiation in the process used for going in and out between the two sectors. Indeed, a higher proportion of graduates working in non-research sectors knew of the existence of a job opportunity by sending spontaneous application letters or reading the classified ads, whereas a higher proportion of graduates holding research positions seem to have used information provided by their former colleges.

\subsection{Variables for engineering schools}

In the model including engineers, it is also taken into account whether the engineer graduated from a 'prestigious' school.

Table 2. How did you know there was a working opportunity in this company?

\begin{tabular}{lcccccc}
\hline & \multicolumn{3}{c}{ Engineers } & \multicolumn{3}{c}{ Doctors } \\
\cline { 2 - 7 } (In \%) & R\&D & Non-R\&D & Total & R\&D & Non-R\&D & Total \\
\hline spontaneous application & 13.1 & 15.1 & 14.6 & 9.1 & 11.7 & 10.1 \\
Organization & 12.0 & 7.8 & 9.0 & 5.8 & 11.7 & 8.1 \\
One of your acquaintances & 20.9 & 22.9 & 22.4 & 34.6 & 35.0 & 34.8 \\
Advertisement & 24.6 & 26.2 & 25.8 & 24.0 & 24.8 & 24.3 \\
Former school & 11.5 & 8.6 & 9.4 & 13.9 & 5.1 & 10.4 \\
Others & 17.8 & 19.3 & 18.9 & 12.5 & 11.7 & 12.2 \\
Total & 100 & 100 & 100 & 100 & 100 & 100 \\
\hline
\end{tabular}

Table 3. Engineering schools

\begin{tabular}{lccc}
\hline (\% of engineers) & R\&D & Non-R\&D & Total \\
\hline Prestigious schools & 12.0 & 9.4 & 10.1 \\
R\&D schools & 22.5 & 15.1 & 17.1 \\
\hline
\end{tabular}

On the other hand, the way in which 'Industrie et Technologies' (2007) ranked the engineering schools of the sample seems to indicate that these schools can be ranked by considering the quantity of funds (technical services, R\&D benefits from enrolment in European programs) they received when doing business with companies in 2006. The first 20 schools were brought together under a variable called 'R\&D schools'. These schools have an average turnover of 3.15 million Euros. This variable was built because we can assume that these schools have close links with corporate R\&D laboratories.

Table 3 shows that twelve per cent of engineers working in R\&D graduated from a 'prestigious school' against 9.4 per cent of engineers working in non-research sectors. On the other hand, 22.5 per cent of engineers in R\&D graduated from 'R\&D schools' against 15.1 per cent of graduates in non-research sectors.

\subsection{Instrumental variables}

In the selection equation, an instrumental variable documents the choice between the two 
sectors but the absence of an impact on wages must be taken into account. ${ }^{8}$ The variable chosen involves the career plans of graduates on the day they finished high school. Indeed, Fox and Stephan (2001) pointed out that considering a career in science is often considered by students as teenagers. This variable is based on items related to the profession and the field graduates wanted to work in by the time they had finished high school. It presents six terms: by the time he has finished high school, the graduate wants to work in research, science, computing, engineering, in another field or he does not have any plan.

Overall, a higher proportion of graduates in non-research sectors had no career plans during their last year of high school compared with graduates currently in the research sector (around 20 per cent against 15 per cent). People hired in the sector were more frequently planning to work in the research sector, in science or engineering. Conversely, a small proportion of them wanted to work in computing (3.7 per cent against 14 per cent for graduates currently holding different positions). Finally, concerning the estimates for doctors, an instrumental variable is added to consider whether a doctor made a post-doctorate work placement. Indeed, Recotillet (2007) showed that a post-doctoral work placement can play the role of a signal at an early stage in the careers of doctors but is not synonymous with earning more in the private sector. In the sample, 40.9 per cent of doctors working in research undertook a post-doctoral work placement whereas 24.8 per cent of them hired in an area other than research did so.

\section{Results}

\subsection{Access to R\&D: analysis of the results of the selection equation}

For all estimates, the independence test (Wald test) is rejected and replaced by the joint dependence of the error terms of the models. The adoption of a 'Mover/Stayer' model is therefore justified in comparison with an estimate by OLS or Oaxaca-Blinder decomposition.

5.1.1 Doctors (the results are presented in Table 4). The way a doctor financed his/her studies is crucial to getting a position in private sector R\&D. Indeed, if a doctor received funding from CIFRE during his/her studies, it greatly increases the probability of getting a position in private sector $R \& D$ compared with a doctor who received another type of financing. The previous degree of a doctor (engineering schools versus university) seems to have no impact on the probability of getting involved in R\&D. On the other hand, the fact that a doctor did a work placement during his/her studies is strongly positive and significant. The field in which a doctor studied has no significant impact on his/her joining R\&D. The fact that the graduate knew of the existence of the job opportunity does not affect the probability of finding jobs in research. Indeed, none of the ways used has a significant impact compared with using acquaintances. The two instrumental variables are significant. The fact of having done a post-doctoral work placement greatly increases the possibilities of becoming a

\footnotetext{
8 There is no real test to assess the exogeneity of instrumental variables. However, these variables are non-significant in the naïve regression for log wage.
} 
researcher. Wanting to work in research during the last year of high school also has a significant positive impact. In contrast, considering career plans during the $\mathrm{PhD}$ has no significant impact. Given these results, professional experience in companies and in private sector research acquired before and during the PhD (CIFRE, work placement) seems to be the selection factor that determines whether or not the candidate will get a position in private sector R\&D.

5.1.2 Graduates from engineering schools. Table 5 shows different results for graduates from engineering school.

Compared with graduates in technology, engineering graduates majoring in 'mathcomputing' are less likely to join $\mathrm{R} \& \mathrm{D}$, whereas engineering graduates majoring in 'mechanics' stand a better chance. Among the methods of job hunting used by a graduate, only the fact of relying on an organization has a significant positive impact (10 per cent) on getting involved in $\mathrm{R} \& \mathrm{D}$ compared with relying on acquaintances. If we refer to the engineering school from which the applicant graduated, the fact of graduating from a prestigious school has a positive but not significant impact on the fact of working in research. On the contrary, the fact that the applicant graduated from a 'R\&D school' greatly increases the opportunities of becoming a researcher (significant at 5 per cent). It seems, therefore, that engineers who graduated from a school that is often in contact with the $R \& D$ laboratories of companies will be more likely to work in research sectors. Finally, the instrumental variable is significant. Indeed, engineers who want to work in research, in science, or as in engineering are more likely to find a job in research sectors compared with graduates who do not have plans during the last year of high school. 
Table 4. Selection equation

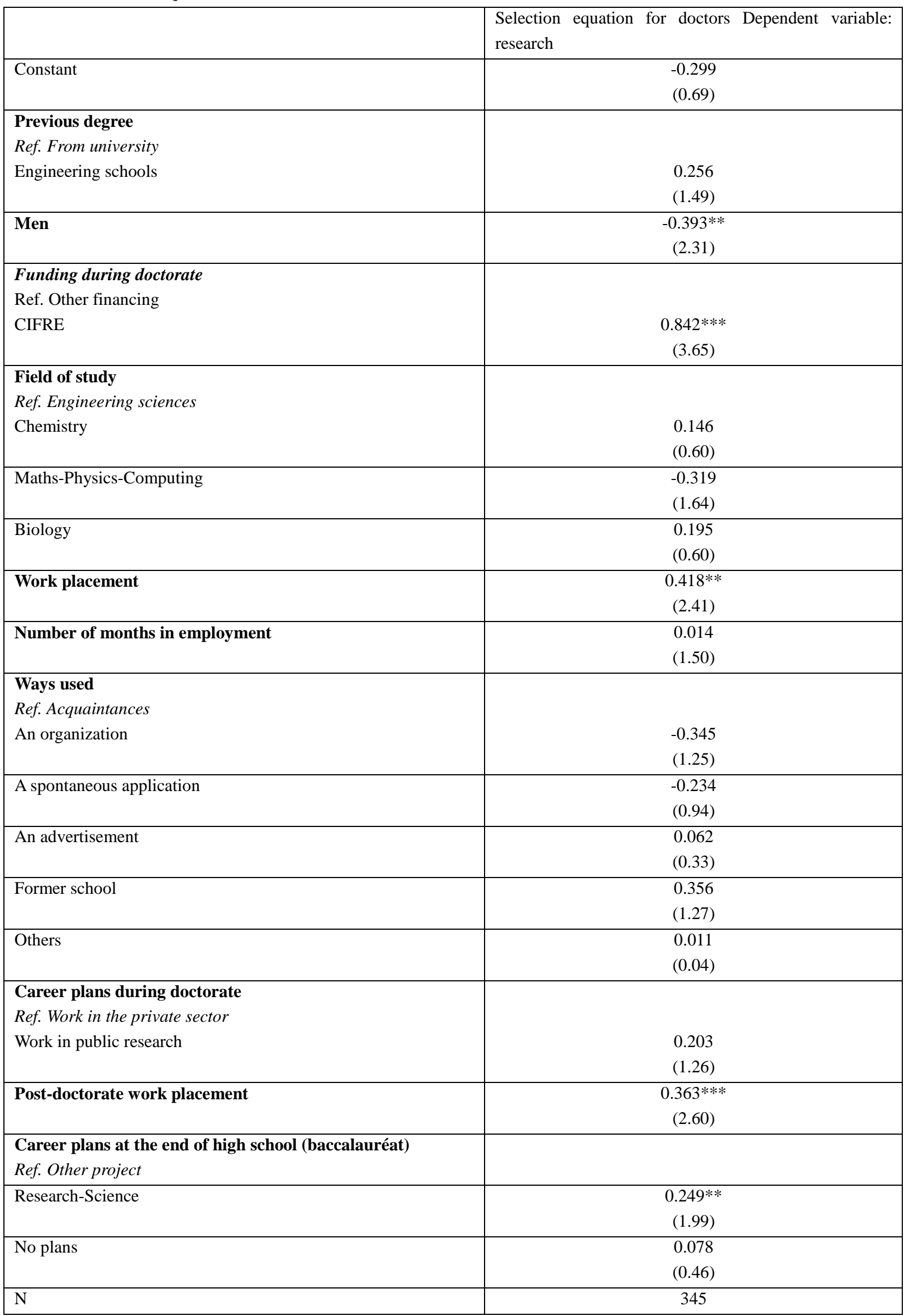

Notes: Absolute value of $\mathrm{z}$ statistics in brackets. ${ }^{* * *},{ }^{* *}$, and * indicate statistical significance at 1,5 , and $10 \%$ levels. 
Table 5. Selection equation for engineers

\begin{tabular}{|c|c|}
\hline \multirow{2}{*}{ Constant } & Selection equation Dependent variable: research \\
\hline & $\begin{array}{c}-0.948 * * * \\
(2.62)\end{array}$ \\
\hline Men & $\begin{array}{l}0.076 \\
(0.60)\end{array}$ \\
\hline \multicolumn{2}{|l|}{$\begin{array}{l}\text { Field of study } \\
\text { Ref. Technology }\end{array}$} \\
\hline Maths-Physics-Computing & $\begin{array}{c}-0.548^{* * *} \\
(2.61)\end{array}$ \\
\hline Agronomy & $\begin{array}{r}-0.230 \\
(1.19)\end{array}$ \\
\hline Other fields of engineering sciences & $\begin{array}{c}-0.0173 \\
(0.97)\end{array}$ \\
\hline Mechanics & $\begin{array}{l}0.273^{*} \\
(1.92)\end{array}$ \\
\hline Biology-Chemistry & $\begin{array}{l}0.194 \\
(0.89)\end{array}$ \\
\hline Number of months in employment & $\begin{array}{l}0.001 \\
(0.12)\end{array}$ \\
\hline $\begin{array}{l}\text { Ways used } \\
\text { Ref. Acquaintances } \\
\text { An organization }\end{array}$ & $\begin{array}{l}0.328 * \\
(1.68)\end{array}$ \\
\hline A spontaneous application & $\begin{array}{l}-0.071 \\
(0.42)\end{array}$ \\
\hline An advertisement & $\begin{array}{l}0.026 \\
(0.18)\end{array}$ \\
\hline Your training organization & $\begin{array}{l}0.267 \\
(1.37)\end{array}$ \\
\hline Others & $\begin{array}{l}0.024 \\
(0.16)\end{array}$ \\
\hline Different degree (from engineer’s) & $\begin{array}{l}-0.202 \\
(1.00)\end{array}$ \\
\hline Prestigious school & $\begin{array}{l}0.113 \\
(0.60)\end{array}$ \\
\hline R\&D school & $\begin{array}{c}0.306^{* *} \\
(2.30)\end{array}$ \\
\hline \multicolumn{2}{|l|}{$\begin{array}{l}\text { Career plans at the end of high school (baccalauréat) } \\
\text { Réf. No plan }\end{array}$} \\
\hline Research-Science & $\begin{array}{c}0.374 * * \\
(2.46)\end{array}$ \\
\hline Engineering & $\begin{array}{c}0.297 * * \\
(2.45)\end{array}$ \\
\hline Computing & $\begin{array}{l}-0.186 \\
(0.97)\end{array}$ \\
\hline Other project & $\begin{array}{l}0.221^{*} \\
(2.02)\end{array}$ \\
\hline $\mathrm{N}$ & 714 \\
\hline
\end{tabular}

Notes: Absolute value of $\mathrm{z}$ statistics in brackets. ${ }^{* * *}, * *$, and * indicate statistical significance at 1, 5, and $10 \%$ levels.

\subsection{Wages in R\&D: earnings functions}


After estimating the selection equation, we can introduce selection effects in wage equations. ${ }^{9}$ The wage equations for doctors and engineers are respectively presented in Table 6 and in Table 7.

5.2.1 Doctors. The funding received by a doctor while he/she was preparing his/her doctorate has a wage impact on both types of sectors. Indeed, the CIFRE funding is assessed in both the research sector (18.3 per cent) and the non-research sector (22 per cent). A previous degree from another engineering school results in wage gains (significant at 10 per cent) only in other areas than research. On the other hand, a work placement ${ }^{10}$ has a significant positive coefficient in both sectors. The wages of a doctor who did a work placement during his/her studies will be higher by 9 per cent in R\&D and 14 per cent in nonresearch sectors. The subject of the $\mathrm{PhD}$ degree appears to have no impact on wages in both types of positions. The fact that a doctor wanted to work in public research has a significantly negative impact in research and non-research sectors. Bender and Heywood (2006) showed that doctors in science working in different sectors than the one they planned to work in during their studies have a low level of satisfaction and lower incomes. Regarding the recruitment process, the fact of contacting their former colleges has a positive impact for doctors, whereas the fact of relying on a university has a negative impact on incomes in nonresearch sectors.

We tested if coefficients were significantly different in $R \& D$ activities and non-R\&D activities. It seems that only the coefficient on former school is statistically different.

5.2.2 Engineers. Only mathematics and physics have a positive impact on wages in nonresearch sectors compared with technology. Completing another degree after graduating in engineering does not bring significant wage gains in either research or non-research sectors. Regarding gender, the same result is found for all graduates. Wage discrimination due to gender early in a career in research does not seem to exist. On the other hand, a somewhat surprising result is the fact that relying on an organization (APEC) causes an increase in wages in the research sector but is not really significant (10 per cent). Finally, engineers from prestigious schools earn more than engineers from other schools. Indeed, being a graduate from a prestigious school leads to a gain of 18 per cent in research sectors and 9 per cent in non-research sectors. On the other hand, being a graduate from a 'R\&D school' results in a positive gain (8.5 per cent, significant at 5 per cent) only in research sectors. We can note that only the coefficient of this variable is statistically different in R\&D activities and non-R\&D activities.

\footnotetext{
9 The wage corresponds to the net monthly wage, plus bonuses. We recognize that this variable has limitations. Indeed, researchers may receive bonuses or royalties when filing a patent.

10 'In “work placement”, doctors who received a CIFRE funding are not taken into account'.
} 
5.3 Measurement of the wage gap between the two types of activities: analysis of predicted wages

The analysis of correlation coefficients of the estimates makes it possible to identify the existence of a positive or negative selection process in research sectors and non-research sectors. The signs of the coefficients of the different estimates are detailed in Table 8. Then, from the parameters of different models, conditional and counterfactual wages can be calculated to construct the indicators presented in Section 3.4. The counterfactual wages were also estimated by the Oaxaca-Blinder decomposition in order to compare results. These results are presented in Table 8. 


\begin{tabular}{|c|c|c|c|c|}
\hline & \multicolumn{2}{|c|}{$\begin{array}{l}\text { Earnings functions Switching } \\
\text { regression }\end{array}$} & \multicolumn{2}{|c|}{ Earnings functions by OLS } \\
\hline & $\mathrm{R} \& \mathrm{D}$ & No R\&D & R\&D & No R\&D \\
\hline Constant & $7.367 * * *$ & $7.687 * * *$ & $7.535 * * *$ & $7.451 * * *$ \\
\hline \multicolumn{5}{|l|}{ Previous degree } \\
\hline \multicolumn{5}{|l|}{ Ref. From university } \\
\hline \multirow[t]{2}{*}{ Engineering schools } & 0.028 & $0.109 *$ & 0.008 & 0.077 \\
\hline & $(0.068)$ & $(1.88)$ & $(0.22)$ & $(1.40)$ \\
\hline \multirow[t]{2}{*}{ Men } & 0.011 & 0.061 & 0.053 & $0.111 *$ \\
\hline & $(0.785)$ & $(1.06)$ & $(1.42)$ & $(2.06)$ \\
\hline \multicolumn{5}{|l|}{ Funding during doctorate } \\
\hline \multicolumn{5}{|l|}{ Ref. Other financing } \\
\hline \multirow[t]{2}{*}{ CIFRE } & $0.183^{* * *}$ & $0.220 * * *$ & $0.093^{*}$ & 0.078 \\
\hline & (3.11) & (2.63) & $(1.81)$ & $(1.06)$ \\
\hline \multicolumn{5}{|l|}{ Field of study } \\
\hline \multicolumn{5}{|l|}{ Ref. Engineering sciences } \\
\hline \multirow[t]{2}{*}{ Chemistry } & 0.053 & -0.044 & 0.026 & -0.074 \\
\hline & $(0.91)$ & $(0.54)$ & $(0.48)$ & $(0.94)$ \\
\hline \multirow[t]{2}{*}{ Maths-Physics-Computing } & 0.009 & 0.004 & 0.045 & 0.049 \\
\hline & $(0.19)$ & $(0.07)$ & $(0.99)$ & $(0.85)$ \\
\hline \multirow[t]{2}{*}{ Biology } & 0.077 & 0.011 & 0.072 & -0.047 \\
\hline & $(1.35)$ & $(0.14)$ & $(1.34)$ & $(0.67)$ \\
\hline \multirow[t]{2}{*}{ Work placement } & $0.092 * *$ & $0.139 * *$ & 0.048 & $0.084^{*}$ \\
\hline & $(2.03)$ & $(2.49)$ & $(1.15)$ & $(1.67)$ \\
\hline \multirow[t]{2}{*}{ Number of months in employment } & $0.007 * * *$ & $0.009 * * *$ & $0.005^{* *}$ & $0.006 * *$ \\
\hline & $(2.94)$ & $(2.96)$ & $(2.13)$ & $(2.26)$ \\
\hline \multicolumn{5}{|l|}{ Ways used } \\
\hline \multicolumn{5}{|l|}{ Ref. Acquaintances } \\
\hline \multirow[t]{2}{*}{ An organization } & -0.110 & $-0.165 *$ & & -0.083 \\
\hline & $(1.43)$ & $(1.95)$ & & $(1.13)$ \\
\hline \multirow[t]{2}{*}{ A spontaneous application } & -0.049 & -0.021 & & 0.01 \\
\hline & $(0.76)$ & $(0.27)$ & & $(0.14)$ \\
\hline \multirow[t]{2}{*}{ An advertisement } & -0.012 & -0.055 & & -0.041 \\
\hline & $(0.26)$ & $(0.91)$ & & $(0.73)$ \\
\hline \multirow[t]{2}{*}{ Former school } & 0.015 & $0.298 * * *$ & & 0.175 \\
\hline & $(0.26)$ & $(2.56)$ & & (1.65) \\
\hline \multirow[t]{2}{*}{ Others } & 0.088 & -0.041 & & -0.037 \\
\hline & $(1.52)$ & $(0.52)$ & & $(0.51)$ \\
\hline Career plans during doctorate & & & & \\
\hline Ref. Work in the private sector & & & & \\
\hline Work in public research & $-0.072 *$ & $-0.094 *$ & $-0.11 * * *$ & $-0.131^{* * *}$ \\
\hline & $(1.77)$ & $(1.82)$ & $(2.92)$ & $(2.80)$ \\
\hline$\sigma 1$ & $0.265 * *$ & & & \\
\hline$\sigma 0$ & & $0.302 * * *$ & & \\
\hline$\sigma 1$ & $0.768 * * *$ & & & \\
\hline$\sigma 0$ & & $0.829 * * *$ & & \\
\hline Wald test, Prob > chi-2 & 0.0156 & & & \\
\hline $\mathrm{R}^{2}$ & & & 0.162 & 0.207 \\
\hline $\mathrm{N}$ & & & 208 & 137 \\
\hline
\end{tabular}


Table 7. Wage equations for engineers

\begin{tabular}{|c|c|c|c|c|}
\hline & \multicolumn{2}{|c|}{$\begin{array}{l}\text { Earnings function Switching } \\
\text { regression }\end{array}$} & \multicolumn{2}{|c|}{ Earnings function by OLS } \\
\hline & R\&D & No $R \& D$ & $\mathrm{R} \& \mathrm{D}$ & No R\&D \\
\hline Constant & $7.066^{* * *}$ & $7.093 * * *$ & $7.35^{* * *}$ & $7.193 * * *$ \\
\hline Men & $\begin{array}{l}0.037 \\
(1.02)\end{array}$ & $\begin{array}{l}0.093 * * * \\
(2.87)\end{array}$ & $\begin{array}{l}0.023 \\
(0.69)\end{array}$ & $\begin{array}{l}0.010 * * * \\
(3.42)\end{array}$ \\
\hline \multicolumn{5}{|l|}{ Field of study } \\
\hline Maths-Physics-Computing & $\begin{array}{l}-0.085 \\
(1.16)\end{array}$ & $\begin{array}{l}0.100^{* *} \\
(2.30)\end{array}$ & $\begin{array}{l}-0.245 \\
(0.33)\end{array}$ & $\begin{array}{l}0.017 \\
(0.45)\end{array}$ \\
\hline Agronomy & $\begin{array}{l}-0.058 \\
(0.99)\end{array}$ & $\begin{array}{l}-0.067 \\
(1.41)\end{array}$ & $\begin{array}{l}-0.045 \\
(0.81)\end{array}$ & $\begin{array}{c}-0.109 * * \\
(2.54)\end{array}$ \\
\hline $\begin{array}{l}\text { Other fields of } \\
\text { engineering sciences }\end{array}$ & $\begin{array}{l}0.001 \\
(0.02)\end{array}$ & $\begin{array}{l}0.001 \\
(0.02)\end{array}$ & $\begin{array}{l}0.013 \\
(0.25)\end{array}$ & $\begin{array}{l}-0.03 \\
(0.77)\end{array}$ \\
\hline Mechanics & $\begin{array}{l}0.042 \\
(0.95)\end{array}$ & $\begin{array}{l}-0.034 \\
(0.90)\end{array}$ & $\begin{array}{l}-0.014 \\
(0.36)\end{array}$ & $\begin{array}{l}0.007 \\
(0.21)\end{array}$ \\
\hline Biology-Chemistry & $\begin{array}{l}-0.015 \\
(0.24)\end{array}$ & $\begin{array}{l}-0.037 \\
(0.62)\end{array}$ & $\begin{array}{l}-0.057 \\
(1.02)\end{array}$ & $\begin{array}{l}0.001 \\
(0.01)\end{array}$ \\
\hline $\begin{array}{l}\text { Number of months in } \\
\text { employment }\end{array}$ & $\begin{array}{l}0.011^{* * *} \\
(3.56)\end{array}$ & $\begin{array}{l}0.014 * * * \\
(6.05)\end{array}$ & $\begin{array}{l}0.011^{* * *} \\
(3.75)\end{array}$ & $\begin{array}{l}0.014^{* * *} \\
(6.86)\end{array}$ \\
\hline $\begin{array}{l}\text { Ways used } \\
\text { Ref. Acquaintances }\end{array}$ & & & & \\
\hline An organization & $\begin{array}{l}0.097^{*} \\
(1.75)\end{array}$ & $\begin{array}{l}-0.068 \\
(1.30)\end{array}$ & $\begin{array}{l}0.057 \\
(1.15)\end{array}$ & $\begin{array}{l}-0.017 \\
(0.35)\end{array}$ \\
\hline A spontaneous application & $\begin{array}{l}-0.016 \\
(0.31)\end{array}$ & $\begin{array}{l}0.064 \\
(1.50)\end{array}$ & $\begin{array}{l}-0.023 \\
(0.48)\end{array}$ & $\begin{array}{l}0.057 \\
(1.47)\end{array}$ \\
\hline An advertisement & $\begin{array}{l}0.010 \\
(0.24)\end{array}$ & $\begin{array}{l}0.003 \\
(0.08)\end{array}$ & $\begin{array}{l}-0.012 \\
(0.31)\end{array}$ & $\begin{array}{l}-0.003 \\
(0.10)\end{array}$ \\
\hline Former school & $\begin{array}{l}0.019 \\
(0.34)\end{array}$ & $\begin{array}{l}-0.060 \\
(1.17)\end{array}$ & $\begin{array}{l}-0.03 \\
(0.61)\end{array}$ & $\begin{array}{l}-0.017 \\
(0.37)\end{array}$ \\
\hline Others & $\begin{array}{l}0.018 \\
(0.02)\end{array}$ & $\begin{array}{l}-0.016 \\
(0.40)\end{array}$ & $\begin{array}{l}0.005 \\
(0.11)\end{array}$ & $\begin{array}{l}-0.01 \\
(0.28)\end{array}$ \\
\hline $\begin{array}{l}\text { Different degree (from } \\
\text { engineer's) }\end{array}$ & 0.022 & 0.039 & 0.054 & 0.030 \\
\hline & $(0.33)$ & $(0.81)$ & $(0.83)$ & $(0.72)$ \\
\hline Prestigious school & $\begin{array}{l}0.180^{* * *} \\
(3.34)\end{array}$ & $\begin{array}{l}0.092 * \\
(1.92)\end{array}$ & $\begin{array}{l}0.173^{* * * *} \\
(3.46)\end{array}$ & $\begin{array}{l}0.131^{* * * *} \\
(3.01)\end{array}$ \\
\hline R\&D school & $\begin{array}{c}0.084^{* *} \\
(2.16)\end{array}$ & $\begin{array}{l}-0.025 \\
(0.70)\end{array}$ & $\begin{array}{l}0.037 \\
(1.06)\end{array}$ & $\begin{array}{l}0.021 \\
(0.63)\end{array}$ \\
\hline s1 & $0.240^{* * *}$ & & & \\
\hline s0 & & $0.313 * * *$ & & \\
\hline r1 & $0.836 * * *$ & & & \\
\hline r0 & & $-0.889 * * *$ & & \\
\hline Wald test $\mathrm{P}>$ Chi-2 & 0.0 & & & \\
\hline$R 2$ & & & 0.179 & 0.173 \\
\hline $\mathrm{N}$ & & 714 & & 523 \\
\hline
\end{tabular}


Table 8. Wage gap between research activities and non-research activities

\begin{tabular}{|c|c|c|c|c|c|c|c|c|c|}
\hline & \multirow{2}{*}{\multicolumn{2}{|c|}{$\begin{array}{l}\text { Coefficient } \\
\text { correlation }\end{array}$}} & \multirow{3}{*}{$\begin{array}{c}\begin{array}{c}\text { Oaxaca-Blinder } \\
\text { decomposition }\end{array} \\
\begin{array}{c}\text { Coefficient } \\
\text { effect }{ }^{a}\end{array}\end{array}$} & \multicolumn{6}{|c|}{ Estimates based on the Mover/Stayer model } \\
\hline & & & & \multicolumn{2}{|c|}{$\begin{array}{c}\text { Conditional } \\
\text { wages }\end{array}$} & \multicolumn{2}{|c|}{$\begin{array}{c}\begin{array}{c}\text { Counterfactual } \\
\text { wages }\end{array} \\
\end{array}$} & \multicolumn{2}{|c|}{ Indicators } \\
\hline & $p_{1}$ & $p_{0}$ & & $y c_{1 \_1 i}$ & $y c_{0 \_0 i}$ & $y c_{0 \_1 i}$ & $y c_{1 \_0 i}$ & $\Pi_{1}$ & $\Pi_{0}$ \\
\hline Engineers & + & - & -0.01 & 7.70 & 7.70 & 7.26 & 7.35 & $0.444^{* * *}$ & $-0.350 * * *$ \\
\hline Doctors & + & + & $0.046^{*}$ & 7.78 & 7.71 & 8.15 & 7.43 & $-0.373 * * *$ & $-0.277 * * *$ \\
\hline
\end{tabular}

Notes: The Student test is used to determine the significance of average differences $(* * *, * *$, *: significant at 1,5 , and $10 \%)$

a For comparison, we report only the second part of the Oaxaca-Blinder decomposition.

5.3.1 Doctors. Estimates related to doctors reveal positive and significant correlation coefficients.

It appears that the 'best performers' profiles (from their unobservable characteristics) are those employed in research sectors. We can conclude that the wages of a doctor who chose to work in research are higher on average than those of a doctor picked from the random sample. The indicators P1 and P0 are significantly negative. It seems that non- research sectors tend to offer higher wages than R\&D for doctors currently working in R\&D and doctors not currently doing research. Therefore it appears that, in the case of doctors, $R \& D$ is less lucrative than non-research activities. This result may suggest a 'preference' of doctors for research because doctors who are currently employed in $R \& D$ would receive higher wages (37.3 per cent) if they worked in non-research activities. But we are talking here of the early stages of a career (3 years after obtaining their $\mathrm{PhD}$ degree), an analysis of wages earned in the long run is needed to determine whether or not this difference is temporary.

We can note that the coefficient of the R\&D variable is positive and only significant at 10 per cent in the model estimated by Oaxaca-Blinder decomposition. The difference in results between the two models is not surprising as it seems that doctors who are the 'best performers' work in R\&D. Not taking into account selection biases tends to overstate starting wages in the research sector.

It is important to remember that the estimates concern the early-career wages. The wage gap found between both types of activities can be interpreted in several ways. First, we can interpret it as 'a learning effect' (Moen, 2005), the young graduates acquire human capital in R\&D activities that can then be exploited in another company or in a different position. Alternatively, the earning gap can be explained by an information asymmetry (Mishagina, 2008). At the beginning of their careers, information on the productivity of young researchers is not available. The employer may decide to offer lower wages to individuals working in research compared with those working in other sectors. When information on the capabilities of the individual to do research is revealed, the less productive researchers move on to different positions, whereas the most productive stay in research and will have a higher wage growth. Only an analysis of the career of researchers could distinguish the different 
hypothesis.

5.3.2 Engineers. Where graduates from engineering schools are concerned, it seems that engineers choose the activity in which they possess a relative advantage. If engineers who are currently in research (non-research) sectors worked in non-research (research) activities, their wages would be lower than those of a graduate randomly picked in the population who works in non-research (research) sectors. In the case of engineers, P1 is significantly positive whereas P0 is significantly negative. This result suggests that graduates from engineering schools are employed in the sector that offers the best wages. Indeed, engineers who are currently employed in $R \& D$ would receive lower wages if they worked in non-research sectors, and vice versa for engineers who are currently employed in non-research sectors. Unlike doctors, in the case of engineers, it does not appear that, early in their careers, $R \& D$ is less lucrative than non-research sectors.

The difference in results between doctors and engineers can be explained by the fact that non-research positions are often a second choice for doctors. In the sample, only 21 per cent of doctors wanted to work in this area during their doctorate. For graduates from engineering schools, working in non-research sectors (production, manufacturing, management, etc.) is a common career choice.

\section{Discussion and conclusion}

This study shows a differentiation in the selection in R\&D between doctors and graduates from engineering schools. Indeed, in the case of doctors, the funding the doctor received (CIFRE) and his/her professional experience are crucial to joining R\&D. This result is similar to those found in other studies (Giret et al., 2007). For engineers, only the engineering school seems to play a role in helping them get positions in research. A graduate from an engineering school who maintains numerous contacts in R\&D firms is more likely to become a researcher, and also receives higher wages in the $R \& D$ sector. In contrast, the prestige of the school does not seem to affect the fact of working in research. A limitation of this study is that we stand early in their careers. The analysis in wage differences suggests that, at the early stages of a career, the R\&D sector is less lucrative than other sectors only for doctors, a fact that could be explained by the 'taste for research' that they seem to have. To validate this hypothesis and better understand the incentives for graduates to become researchers, it is necessary to extend this study to an analysis of wage increase and career evolution in the sector of research and development. 
Are seen as working in $\mathrm{R} \& \mathrm{D}$, graduates declaring the $\mathrm{PCS}^{11}$ following (Audric-Lerenard and Topol, 1999):

383A: Electrical Engineers of Research and Development 384A: Mechanical Engineers of Research and Development 385A: Engineers of Research and Development for processing industries 386A: Engineers of Research and Development for other industries 474B: Mechanical Technicians of Research and Development 475A: Technicians of Research and Development for processing industries 625b: Skilled and trained laboratory staff: Food Chemistry Biology Pharmacy

Appendix B: Descriptive statistics

Table B1. Descriptive Statistics: doctors

\begin{tabular}{|c|c|c|c|}
\hline Variables & R\&D sector & Not R\&D sector & Both sectors \\
\hline \multicolumn{4}{|l|}{ Degree } \\
\hline From an engineering school & 33.6 & 23.3 & 29.6 \\
\hline From a university & 66.3 & 76.6 & 70.4 \\
\hline \multicolumn{4}{|l|}{ Gender } \\
\hline Men & 65.9 & 77.4 & 70.4 \\
\hline Women & 34.1 & 22.6 & 29.6 \\
\hline \multicolumn{4}{|l|}{ Funding } \\
\hline CIFRE & 27.9 & 13.9 & 22.3 \\
\hline \multicolumn{4}{|l|}{ Subject } \\
\hline Biology & 26.4 & 21.9 & 24.6 \\
\hline Chemistry & 20.2 & 13.9 & 17.7 \\
\hline Mathematics-Physics-Computing & 30.3 & 43.8 & 35.7 \\
\hline Engineering sciences & 23.1 & 20.4 & 22.0 \\
\hline \multicolumn{4}{|l|}{ Career plans during doctorate } \\
\hline Work in public research & 37 & 37.2 & 37.1 \\
\hline Work placement & 39.4 & 35.8 & 38 \\
\hline Post-doctorate & 40.9 & 24.8 & 34.5 \\
\hline \multicolumn{4}{|l|}{ Hired thanks to } \\
\hline A spontaneous application & 9.1 & 11.7 & 10.1 \\
\hline An organization & 5.8 & 11.7 & 8.1 \\
\hline One of your acquaintances & 34.6 & 35.0 & 34.8 \\
\hline An advertisement & 24.0 & 24.8 & 24.3 \\
\hline Your former school & 13.9 & 5.1 & 10.4 \\
\hline Others & 12.5 & 11.7 & 12.2 \\
\hline \multicolumn{4}{|c|}{ Career plans before finishing high school (baccalauréat) } \\
\hline To work in research or science & 46.6 & 37.9 & 43.2 \\
\hline To become an engineer & 13.0 & 7.3 & 10.7 \\
\hline To work in computing & 2.9 & 10.9 & 6.1 \\
\hline Other project & 22.1 & 26.3 & 23.8 \\
\hline No plans & 15.4 & 17.5 & 16.2 \\
\hline
\end{tabular}

11 The PCS are socio-professional categories determined by the National Institute of Statistics and Economic Studies (INSEE). 
Table B2. Descriptive statistics: graduates of engineering schools

\begin{tabular}{lccc}
\hline \multicolumn{1}{c}{ Variables } & $\begin{array}{c}\text { R\&D } \\
\text { sector }\end{array}$ & $\begin{array}{c}\text { Not R\&D } \\
\text { sector }\end{array}$ & $\begin{array}{c}\text { Both } \\
\text { sectors }\end{array}$ \\
\hline Gender & & & \\
Men & 79.0 & 76.2 & 77.0 \\
Field of study & & & \\
Biology-Chemistry & 8.9 & 5.9 & 6.7 \\
Agronomy & 9.4 & 13.0 & 12.0 \\
Mathematics-Physics-Computing & 4.7 & 18.2 & 14.6 \\
Technology & 26.7 & 25.0 & 25.5 \\
Mechanics & 38.2 & 22.0 & 26.3 \\
Other fields of engineering & 12.0 & 15.9 & 14.8 \\
sciences & & & \\
Hired thanks to & & & \\
A spontaneous application & 13.1 & 15.1 & 14.6 \\
An organization & 12.0 & 7.8 & 9.0 \\
One of your acquaintances & 20.9 & 22.9 & 22.4 \\
An advertisement & 24.6 & 26.2 & 25.8 \\
Your former school & 11.5 & 8.6 & 9.4 \\
Others & 17.8 & 19.3 & 18.9 \\
Career plans before finishing & & & \\
high school (baccalauréat) & & & \\
To work in research or science & 9.9 & 10.5 & 10.4 \\
To become an engineer & 35.6 & 20.1 & 24.2 \\
To work in computing & 3.7 & 14.0 & 11.2 \\
Other project & 36.1 & 34.8 & 35.2 \\
No plans & 14.7 & 20.7 & 19.0 \\
\hline & & & \\
\hline
\end{tabular}




\section{References}

Audric-Lerenard A. and Topol A. (1999) 'Chercheur : un métier en expansion qui permet l'embauche de jeunes diplômés’, Premières synthèses, n³7-02, DARES, ministère de l'Emploi, septembre.

Becker F. S. (2010) 'Why Don’t Young People Want to Become Engineers? Rational Reasons for Disappointing Decisions’, European Journal of Engineering Education 2010(35): 349366.

Beltramo J. P. and Paul J. J. (1994) 'Les rémunérations et les carrières des chercheurs en entreprises', Paper presented at 13th World Congress of Sociology, Bielefeld, Germany, 1823 July.

Beltramo J. P., Paul J. J. and Perret C. (2000) 'The Recruitment of Researchers and the Organisation of Scientific Activity in Industry', International Journal of Technology Management 22: 811- 834.

Bender K. A. and Heywood J. S. (2006) 'Education Mismatch among Ph.D.s: Determinants and Consequences’, NBER Working Papers 12693.

Biddle J. and Roberts K. (1994) 'Private Sector Scientist and Engineers and the Transition to Manage- ment', Journal of Human Resources 29: 82-107.

Blinder A. S. (1973) 'Wage Discrimination: Reduced Form and Structural Estimates', Journal of Human Resources 8: 436-455.

Bourdon J. and Paul J. J. (1992) 'Une analyse hédonique du goût pour la recherche', Paper presented at the Journées de Micro-économie appliquée, Strasbourg.

Brown C. and Linden G. (2008) 'Is There a Shortage of Engineering Talent in the US?', Center for Work, Technology, and Society Working Paper, University of California, Berkley.

Butz W. P., Bloom G. A., Gross M. E., Kelly T. K., Kofner A. and Rippen H. E. (2003) 'Is There a Shortage of Scientists and Engineers? How Would We Know?', Rand Issue Paper Science and Technology.

Duhautois R. and Maublanc S. (2005) 'Les carrières des chercheurs dans les entreprises privées’, Rapport de Recherche du Centre d’Etude de l’Emploi, miméo.

Duhautois R. and Maublanc S. (2006) 'Chercheurs dans le privé : la place des docteurs', Connaissance de l’Emploi n²6, Centre d’Etudes de l’Emploi.

Dupuy A. and Smits W. (2009) 'How Large Is the Compensating Wage Differential for R\&D Workers?', Discussion Papers 4194, Institute for the Study of Labor (ROA), Maastricht.

Fox M. F. and Stephan P. (2001) 'Careers of Young Scientists: Preferences, Prospects and Realities by Gender and Field’, Social Studies of Science 31: 109-122.

Gago J. M. (2004) 'Europe Needs More Scientists', Report by the High Level Group on Increasing Human Resources for Science and Technology in Europe. 
Giret J. F., Perret C. and Recotillet I. (2003) 'Les jeunes scientifiques dans le secteur privé : quel rendement de la formation doctorale?’ in Euzebi C. (ed.) Mondialisation et régulation sociale, Paris: L’Harmattan: 841-854.

Giret J. F., Perret C. and Recotillet I. (2007) 'Le recrutement des jeunes docteurs dans le secteur privé', Revue d'économie industrielle 119: 85-102.

Graham J. and Smith S. (2005) 'Gender Differences in Employment and Earnings in Science and Engineering in the US’, Economics of Education Reviews 24: 341-354.

Granovetter M. (1995) Getting a Job: A Study of Contacts and Careers, Chicago, IL: University of Chicago Press.

Hamilton B. H. and Nickerson J. A. (2003) 'Correcting for Endogeneity in Strategic Management Research’, Strategic Organization 1: 51-78.

Heckman J. J. (1979) 'Sample Selection Bias as a Specification Error', Econometrica 47: 153-161. Industrie et Technologies (2007) 'R\&D industrielle: le 12ème palmarès des écoles d'ingénieur', October 2007.

Lam A. (2001) 'Changing R\&D Organisation and Innovation: Developing the New Generation of R\&D Knowledge Workers', Paper presented at the conference The Contribution of European Socio- economic Research to the Benchmarking of RTD Policies in Europe, DGV, Brussels: European Commission: 15-16 March.

Lassibille G. (2001) 'Earnings Distribution among Spanish Engineers: Research vs. Nonresearch Occupation', Research Policy 30: 673-680.

Levin S. G. and Stephan P. E. (1991) 'Research Productivity over the Life Cycle: Evidence for Academic Scientists’, American Economic Review 81: 114-132.

Lokshin M. and Zurab S. (2004) 'Maximum Likelihood Estimation of Endogenous Switching Regres- sion Models’, Stata Journal 4: 282-289.

Maddala G. S. (1983) Limited-dependent and Qualitative Variables in Econometrics, Cambridge: Cambridge University Press.

Mangematin V. (2000) 'PhD Job Market: Professional Trajectories and Incentives during the PhD’, Research Policy 29: 741-756.

Melly B. (2005) 'Public-Private Sector Wage Differentials in Germany: Evidence from Quantile Regression’, Empirical Economics 30: 505-520.

Mishagina N. (2008) 'Career Dynamics of Doctoral Scientists and Engineers’, Working Paper, Economic Department, Queen’s University.

Moen J. (2005) 'Is Mobility of Technical Personnel a Source of R\&D Spillovers?', Journal of Labor Economics 23: 81-114.

Oaxaca R. (1973) 'Male-Female Wage Differentials in Urban Labor Markets’, International Economic Review 14: 693-709.

Observatoire de l'emploi scientifique (2007) 'État des lieux de l'emploi scientifique en 
France’, Rapport au Ministère de l’enseignement supérieur et de la recherche.

Rebick M. E. (2000) 'The Importance of Networks in the Market for University Graduates in Japan: A Longitudinal Analysis of Hiring Patterns', Oxford Economic Paper 52: 471-496.

Recotillet I. (2007) 'PhD Graduates with Post-doctoral Qualification in the Private Sector: Does It Pay Off ?’, Labour 21: 473-502.

Redor D. (2004) 'La mobilité des chercheurs dans le système d’innovation français', Economies et Sociétés 3: 2207-2240.

Roberts G. (2002) 'Set for Success': The Supply of People with Science, Technology, Engineering and Mathematics Skills, London: HM Treasury.

Saloner G. (1985) 'Old Boy Networks as Screening Mechanisms', Journal of Labor Economics 3: 255-267.

Simon C. J. and Warner J. T. (1992) 'Matchmaker, Matchmaker: The Effect of Old Boy Networks on Job Match Quality, Earning and Tenure', Journal of Labor Economics 10: 306330.

Stern S. (2004) 'Do Scientists Pay to Be Scientists?’, Management Science 50: 835-853.

Weiss A. (1980) 'Job Queues and Layoffs in Labor Markets with Flexible Wages', Journal of Political Economy 88: 526-538.

Zenger T. R. and Lazzarini J. S. G. (2004) 'Compensating for Innovation: Do Small Firms Offer High-powered Incentives That Lure Talent and Motivate Effort?', Managerial and Decision Economics 25: 329-345. 